\title{
Erratum to: Implant of Polymer Containing Pentacyclic Triterpenes from Eugenia punicifolia Inhibits Inflammation and Activates Skeletal Muscle Remodeling
}

Paulo Emílio C. Leite · Katia G. Lima-Araújo •

Guilherme R. França • Jussara Lagrota-Candido •

Wilson C. Santos · Thereza Quirico-Santos

Published online: 17 June 2014

(C) L. Hirszfeld Institute of Immunology and Experimental Therapy, Wroclaw, Poland 2014

Erratum to: Arch Immunol Ther Exp

DOI 10.1007/s00005-014-0291-0

Unfortunately, in Fig. 7, panels $\mathrm{c}$ and $\mathrm{d}$ are omitted in the original publication of the article. The missing figure panels are given below:

The online version of the original article can be found under doi:10.1007/s00005-014-0291-0.

P. E. C. Leite · G. R. França · T. Quirico-Santos ( ()

Department of Cellular and Molecular Biology,

Institute of Biology, Fluminense Federal University,

Niterói, RJ 24020-141, Brazil

e-mail: tquirico@vm.uff.br

K. G. Lima-Araújo · W. C. Santos

School of Pharmacy, Fluminense Federal University,

Niterói, RJ, Brazil

J. Lagrota-Candido

Department of Immunobiology, Institute of Biology,

Fluminense Federal University, Niterói, RJ, Brazil

W. C. Santos

Instituto Teófilo Hernando, Universidad Autónoma de Madrid,

Madrid, Spain

Present Address:

P. E. C. Leite

Instituto Nacional de Metrologia, Qualidade e Tecnologia

(INMETRO-RJ), Rio de Janeiro, Brazil 
A C57BL10 mice

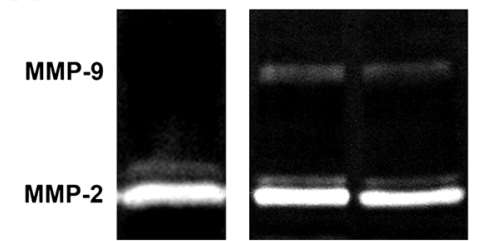

D Bp-induced
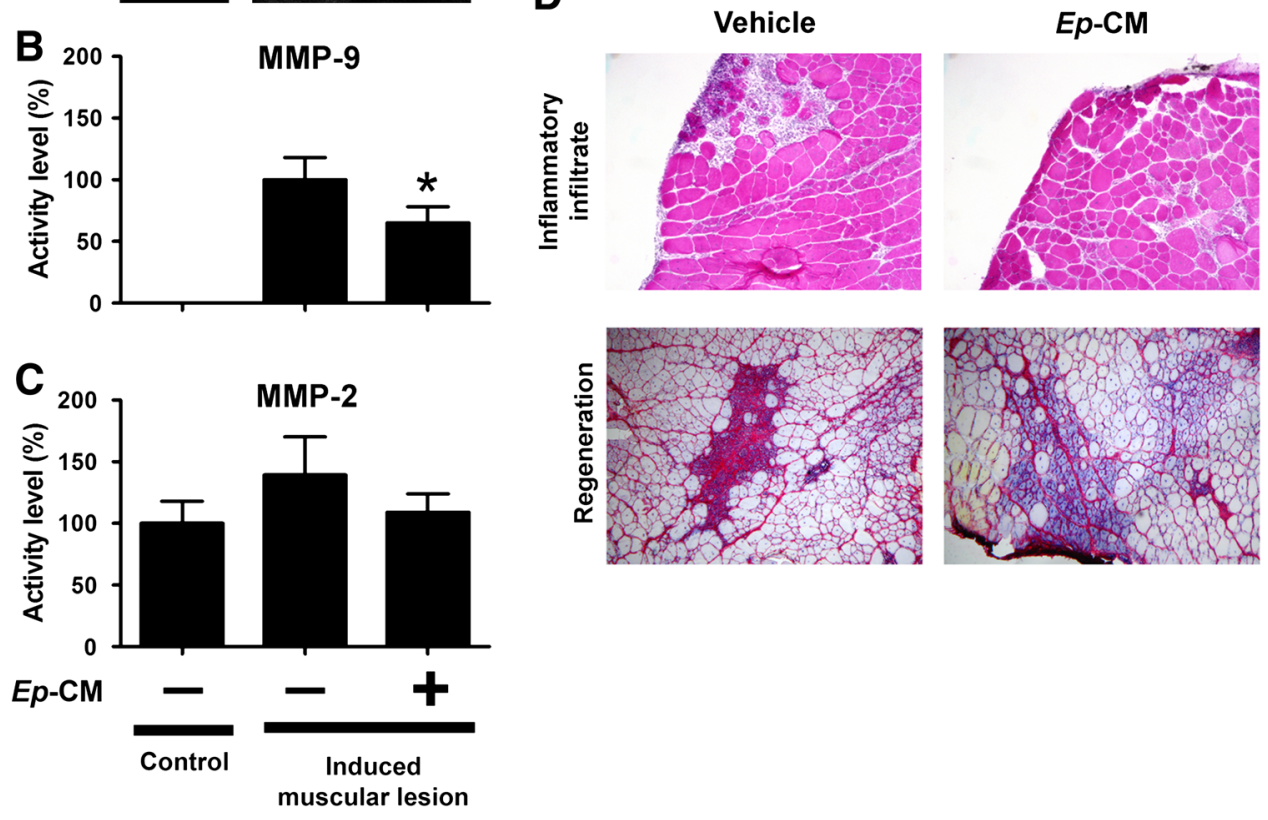